\title{
BASIC MOTOR COMPETENCIES - MOBAK RELATIONSHIPS WITH ACTIVE LEISURE TIME, SOCIODEMOGRAPHIC AND ANTHROPOMETRIC INDICATORS
}

\section{Laura Tumynaitè}

Lithuanian Sports University, Kaunas, Lithuania

\begin{abstract}
ANNOTATION
The research literature has shown that the earlier studies rather narrowly focused on motor skills and competencies in physical activities of primary school children age groups. In the early childhood children begin to explore the environment and develop motor skills in certain groups. One of them is known as the fundamental motor skills, which are divided into "self-movement" and "object movement". These skills form the basis for future movement and physical activity. One of the motor skills of the analytical methods is MOBAK. We tried to discover the relationships between physical activity and sociodemographic as well as anthropometric indicators.
\end{abstract}

Keywords: motor skills, physical activity, sociodemographic and anthropometric indicators.

\section{INTRODUCTION}

Relevance of the theme. Literature analysis showed that earlier studies narrowly examined motor skills and competencies and their role in physical activities. In the early childhood, children begin to explore the environment and thus develop motor skills in certain groups. One of them is known as the fundamental motor skills, which are divided into "self-movement" and "Object movement". "Self-management" skills include body movements in space and are referred to as running, carrying, something transcending, jumping, sliding and canter (Haywood, Getchell, 2015). "Object management" skills consist of object manipulation and capacity to manage them. "Object Management" forms are throwing, catching, jumping, kicking, striking and tossing (Haywood, Getchell, 2005). These skill forms are the basis for future child movement and physical activity and leisure time (Clark, Metcalfe, 2012). Basically, these fundamental motor skills are closely associated with forms of physical activity and they occur as a result of physical activity.

Research problem. If children cannot briskly run, jump, catch, throw, or make other physical actions, they have limited opportunities to engage in physical activity later in life. As a result, a growing body will not have the necessary skills to engage in physical activities. All these motor skills can be called physical tasks, which the children have to perform without any preparation. They are like a child's daily physical activities that are essential to the growth of a young organism. They encourage movement or physical activity (Stodden at el., 2008).

Problem exploration. As the European studies show, physical activity is important for the prevention of cardiovascular diseases, weak muscle strength, low bone density and similar health problems to avoid (Andersen et al., 2006; Valdimarsson et al., 2006; Linden et al., 2007). The early childhood years (the period up to 9 years of age) is called the critical period. It is a child's development gap, the developing motor skills that affect the child's physical, social and cognitive development. Infantile child's physical development is seen in the light of the development of motor 
skills, which have a significant impact on the child's development of different systems and learning (Cheatem, Hammond, 2000; Cools De Martelaer et al., 2009).

The aim of the study was to discover the relationships between MOBAK and physical activity, sociodemographic and anthropometric indicators.

The object of the research - motor skills in connection with physical activity, sociodemographic and anthropometric indicators.

\section{RESEARCH METHODS}

Target group. The study included 129 first-grade students from a variety of Kaunas and Kaunas district schools. The study participants were selected applying convenience sampling strategy. In study parcipated 68 boys (52.7\%) and 61 girls (47.3\%).

Methods and research organization. The study was carried out in three stages: the first stage - selection of the socio-demographic indicators and physical activity, in the secondanthropometric indicators of measurement and the third - the application of the battery of tests MOBAK first grade students.

Total organized physical activity of primary grade students was determined by estimating the time spent in physical education classes and active leisure time sports activities in minutes per week. Among 129 study participants, 82 students (64\%) engaged in organized sports activities after school, 2 of them did not answer. Anthropometric data: height, weight, body mass index (BMI) and fat mass were determined using the TANITA (TBF-300) of the body analyser scales. MOBAK test battery. Student's motor skills were assessed using a battery of tests MOBAK (Herrmann et al., 2015). The test consists of a battery of eight tests designed to measure object (item) management: an attempt to hit the ball to the target, catching a ball, basketball dribble and drippling, and body control and its influencing factors: the balance rolling, canter and sideways movement. A detailed description of the methodology presented in the first and second tables.

Table 1. MOBAK test battery “Object movement" detailed description

\begin{tabular}{|l|l|l|l|l|}
\hline \multicolumn{5}{|c|}{ Object movement } \\
\hline Qualification & Throwing (1) & Catching (2) & Bouncing (3) & Dribbling (4) \\
\hline target. & Citting a small & Catching a ball. & $\begin{array}{l}\text { Bouncing a ball } \\
\text { without losing } \\
\text { control. }\end{array}$ & $\begin{array}{l}\text { Dribbling a ball } \\
\text { without losing } \\
\text { control. }\end{array}$ \\
\hline Test item & $\begin{array}{l}\text { The child throws } \\
\text { from a } 2 \mathrm{~m} \\
\text { distance } \\
\text { at a target with } 6 \\
\text { juggling balls. }\end{array}$ & $\begin{array}{l}\text { The test leader } \\
\text { drops the ball, } \\
\text { the } \\
\text { child catches the } \\
\text { ball after the } \\
\text { turning } \\
\text { point. }\end{array}$ & $\begin{array}{l}\text { The child stands } \\
\text { behind a marked } \\
\text { line and bounces a } \\
\text { small basketball } \\
\text { along the corridor } \\
\text { until the finish line } \\
\text { without losing the } \\
\text { ball. }\end{array}$ & $\begin{array}{l}\text { The child stands } \\
\text { behind a marked } \\
\text { line and dribbles } \\
\text { with the ball along } \\
\text { a corridor until the } \\
\text { finish line without } \\
\text { losing the ball. }\end{array}$ \\
\hline & $\begin{array}{l}\text { Hitting the target } \\
\text { counts as a point. } \\
\text { Overhead casts } \\
\text { only (elbow high, }\end{array}$ & $\begin{array}{l}\text { The ball is to be } \\
\text { caught after the } \\
\text { rebound when } \\
\text { still in the air. }\end{array}$ & $\begin{array}{l}\text { The ball can be } \\
\text { bounced with two } \\
\text { hands. The ball } \\
\text { may not be held or }\end{array}$ & $\begin{array}{l}\text { The ball can be } \\
\text { dribbled with both } \\
\text { feet. The ball may } \\
\text { not be lost. The }\end{array}$ \\
\hline
\end{tabular}




\begin{tabular}{|c|c|c|c|c|}
\hline & $\begin{array}{l}\text { extension of the } \\
\text { forearm). }\end{array}$ & & $\begin{array}{l}\text { lost. The child } \\
\text { must not stop and } \\
\text { must bounce the } \\
\text { ball at least } 5 \\
\text { times. } \\
\text { The child may not } \\
\text { leave the corridor. }\end{array}$ & $\begin{array}{l}\text { child must not stop. } \\
\text { At least } 5 \text { contacts } \\
\text { with the ball. No } \\
\text { side steps. } \\
\text { The child may not } \\
\text { leave the corridor. }\end{array}$ \\
\hline Evaluation & $\begin{array}{l}6 \text { attempts, } \\
\text { amount of hits is } \\
\text { recorded. }\end{array}$ & $\begin{array}{l}6 \text { attempts, } \\
\text { amount of balls } \\
\text { caught is } \\
\text { recorded. }\end{array}$ & $\begin{array}{l}2 \text { attempts, amount } \\
\text { of successful } \\
\text { attempts is } \\
\text { recorded. }\end{array}$ & $\begin{array}{l}2 \text { attempts, amount } \\
\text { of successful } \\
\text { attempts is } \\
\text { recorded. }\end{array}$ \\
\hline Test set-up & $\begin{array}{l}\text { A target is placed } \\
\text { at a } 1.30 \mathrm{~m} \text { height. } \\
\text { A scratch line is } \\
\text { placed } 2 \mathrm{~m} \text { away } \\
\text { from the target. }\end{array}$ & $\begin{array}{l}\text { The test leader } \\
\text { drops the ball } \\
\text { from a } 2 \mathrm{~m} \\
\text { height and } 1.30 \\
\mathrm{~m} \text { distance so } \\
\text { that the ball } \\
\text { reaches a height } \\
\text { of at } \\
\text { least } 1.30 \mathrm{~m} \\
\text { after it has } \\
\text { touched the } \\
\text { ground. }\end{array}$ & $\begin{array}{l}\text { Marking a corridor } \\
\text { using tape }(5 \mathrm{~m} \mathrm{x} \\
1 \mathrm{~m}) .\end{array}$ & $\begin{array}{l}\text { Marking a corridor } \\
\text { using tape }(5 \mathrm{~m} \mathrm{x} \\
1 \mathrm{~m}) .\end{array}$ \\
\hline Materials & $\begin{array}{l}\text { - } 6 \text { juggling balls } \\
\text { - } 1 \text { target } \\
\text { (diameter: } 40 \mathrm{~cm}) \\
\text { - Scratch line }\end{array}$ & $\begin{array}{l}\text { - } 1 \text { small rubber } \\
\text { ball or tennis } \\
\text { ball } \\
\text { - Ground } \\
\text { markings }\end{array}$ & $\begin{array}{l}\text { - } 1 \text { small basketball } \\
\text { (size 3, diameter: } \\
17 \mathrm{~cm} \text { ) } \\
\text { - Ground markings }\end{array}$ & $\begin{array}{l}\text { - } 1 \text { (soft) ball } \\
\text { (140 g, diameter: } \\
18 \mathrm{~cm}) \\
\text { - Ground markings }\end{array}$ \\
\hline
\end{tabular}

Table 2. MOBAK test battery "Self-movement" detailed description

\begin{tabular}{|c|c|c|c|c|}
\hline \multicolumn{5}{|c|}{ Self-movement } \\
\hline & Balancing (5) & Rolling(6) & Jumping (7) & $\begin{array}{l}\text { Moving } \\
\text { sideways (8) }\end{array}$ \\
\hline Qualification & $\begin{array}{l}\text { Balancing across a } \\
\text { see-saw }\end{array}$ & Rolling forward & $\begin{array}{l}\text { Jumping forward } \\
\text { continuously }\end{array}$ & $\begin{array}{l}\text { Continuous } \\
\text { lateral stepping }\end{array}$ \\
\hline Test item & $\begin{array}{l}\text { The child balances } \\
\text { across a seesawing } \\
\text { long bench } \\
\text { without leaving } \\
\text { the bench. }\end{array}$ & $\begin{array}{l}\text { The child performs } \\
\text { a roll forward } \\
\text { fluently } \\
\text { and is able to stand } \\
\text { afterwards. }\end{array}$ & $\begin{array}{l}\text { The child jumps } \\
\text { between and } \\
\text { beneath } \\
\text { the carpet tiles } \\
\text { fluently. The } \\
\text { child has to jump } \\
\text { on one leg } \\
\text { between } \\
\text { the tiles and with } \\
\text { straddled legs } \\
\text { beneath the tiles. }\end{array}$ & $\begin{array}{l}\text { The child starts } \\
\text { at the first cone, } \\
\text { moves sideways } \\
\text { to the second } \\
\text { cone } \\
\text { and moves } \\
\text { sideways back to } \\
\text { the first cone } \\
\text { without changing } \\
\text { his or her } \\
\text { viewing } \\
\text { direction. } \\
\text { Moving back and } \\
\text { forth twice } \\
\text { counts as one } \\
\text { trial. }\end{array}$ \\
\hline
\end{tabular}




\begin{tabular}{|c|c|c|c|c|}
\hline Criteria & $\begin{array}{l}\text { Fluent crossing of } \\
\text { the bench without } \\
\text { stopping or } \\
\text { leaving it. Normal } \\
\text { walking } \\
\text { (no half steps). } \\
\text { The child may } \\
\text { not speed up or } \\
\text { jump down at the } \\
\text { end. }\end{array}$ & $\begin{array}{l}\text { Fluent execution } \\
\text { of movement } \\
\text { without stopping. } \\
\text { No rolling off the } \\
\text { sides. } \\
\text { Hands can be used } \\
\text { for support. The } \\
\text { child may not roll } \\
\text { or stand up with } \\
\text { crossed legs. }\end{array}$ & $\begin{array}{l}\text { The carpet tiles } \\
\text { are not to be } \\
\text { touched. } \\
\text { The child must } \\
\text { jump fluently } \\
\text { without stopping } \\
\text { for more than } 1 \\
\text { second. } \\
\text { The take-off leg } \\
\text { between the } \\
\text { tiles can be chosen } \\
\text { freely. }\end{array}$ & $\begin{array}{l}\text { Fluent side } \\
\text { shuffles. The legs } \\
\text { never } \\
\text { cross; the feet } \\
\text { stay parallel to } \\
\text { the ground } \\
\text { marking and at } \\
\text { ground level. } \\
\text { The hips stay } \\
\text { parallel to the } \\
\text { marking. }\end{array}$ \\
\hline Evaluation & $\begin{array}{l}2 \text { attempts, } \\
\text { amount of } \\
\text { successful } \\
\text { attempts is } \\
\text { recorded. }\end{array}$ & $\begin{array}{l}2 \text { attempts, amount } \\
\text { of successful } \\
\text { attempts is } \\
\text { recorded. }\end{array}$ & $\begin{array}{l}2 \text { attempts, } \\
\text { amount of } \\
\text { successful } \\
\text { attempts is } \\
\text { recorded. }\end{array}$ & $\begin{array}{l}2 \text { attempts, } \\
\text { amount of } \\
\text { successful } \\
\text { attempts is } \\
\text { recorded. }\end{array}$ \\
\hline Test set-up & $\begin{array}{l}\text { A long bench is } \\
\text { placed upside- } \\
\text { down } \\
\text { on a springboard, } \\
\text { forming a see-saw } \\
\text { secured with } \\
\text { gymnastic mats. }\end{array}$ & $\begin{array}{l}2 \text { gymnastics mats } \\
\text { are placed in a } \\
\text { row. }\end{array}$ & $\begin{array}{l}4 \text { carpet tiles are } \\
\text { placed in a row } \\
\text { with a } 40 \mathrm{~cm} \text { gap } \\
\text { between them. }\end{array}$ & $\begin{array}{l}2 \text { cones are } \\
\text { placed on a } \\
\text { marking at a } \\
\text { distance of } 3 \mathrm{~m} \\
\text { from each other. } \\
\text { Side-lines are } \\
\text { marked. }\end{array}$ \\
\hline Qualification & $\begin{array}{l}\text { - } 1 \text { long bench (w: } \\
10 \mathrm{~cm}, 1: 4 \mathrm{~m}) \\
\text { - } 1 \text { springboard (h: } \\
18-21 \mathrm{~cm}) \\
\text { - } 4 \text { gymnastics } \\
\text { mats }\end{array}$ & $\begin{array}{l}\text { - } 2 \text { gymnastics } \\
\text { mats }\end{array}$ & $\begin{array}{l}\text { - } 4 \text { carpet tiles }(40 \\
\mathrm{cm} \times 40 \mathrm{~cm}, 4 \\
\mathrm{~mm} \text { thick) }\end{array}$ & $\begin{array}{l}-2 \text { marking } \\
\text { cones } \\
\text { - Ground } \\
\text { markings }\end{array}$ \\
\hline
\end{tabular}

Research organization and execution. Investigations were carried out in four Kaunas and Kaunas district schools. The first stage was to investigate physical activity. Physical activity was studied using a questionnaire survey where the first-grade students had to identify exactly how many minutes per week they engaged in organized physical activity after school. The second stage was meant to collect anthropometric data: height, weight, BMI and fat mass using the body analyser scales TANITA (TBF-300). The third stage was for the first grade students' motor skills using MOBAK test battery. Following the instructions, the students had the opportunity to try every test twice. The study was conducted according to the study protocol, which recorded MOBAK performance test results $(0=$ test failed, $1=$ test performed $)$. Each student had their own protocol separately for "selfmovement" and "object movement". For each test, they had 6 or 2 trials, which were recorded and summed.

Mathematical Statistical Analysis. Statistical analysis of data was performed using SPSS for Windows 19.0 software (SPSS Inc., Chicago, USA) and MPlus statistical software package. Averages and standard deviations were calculated using descriptive statistics. Motor skills and expected interface factors were assessed using hierarchical regression analysis. Motor skill factor 
structure was assessed using confirmatory factor analysis. The study results demonstration employed Microsoft Office Excel 2007 software.

\section{RESEARCH RESULTS}

The first figure shows the "object management" part of the battery of tests MOBAK including all movements with the Object. The study shows that object management of first grade students depends on how much time per week children are engaged in organized physical activity $(\mathrm{p}<0.05)$. Primary school age and more time spent engaging in organized physical activity demonstrated a better performance of this test result.

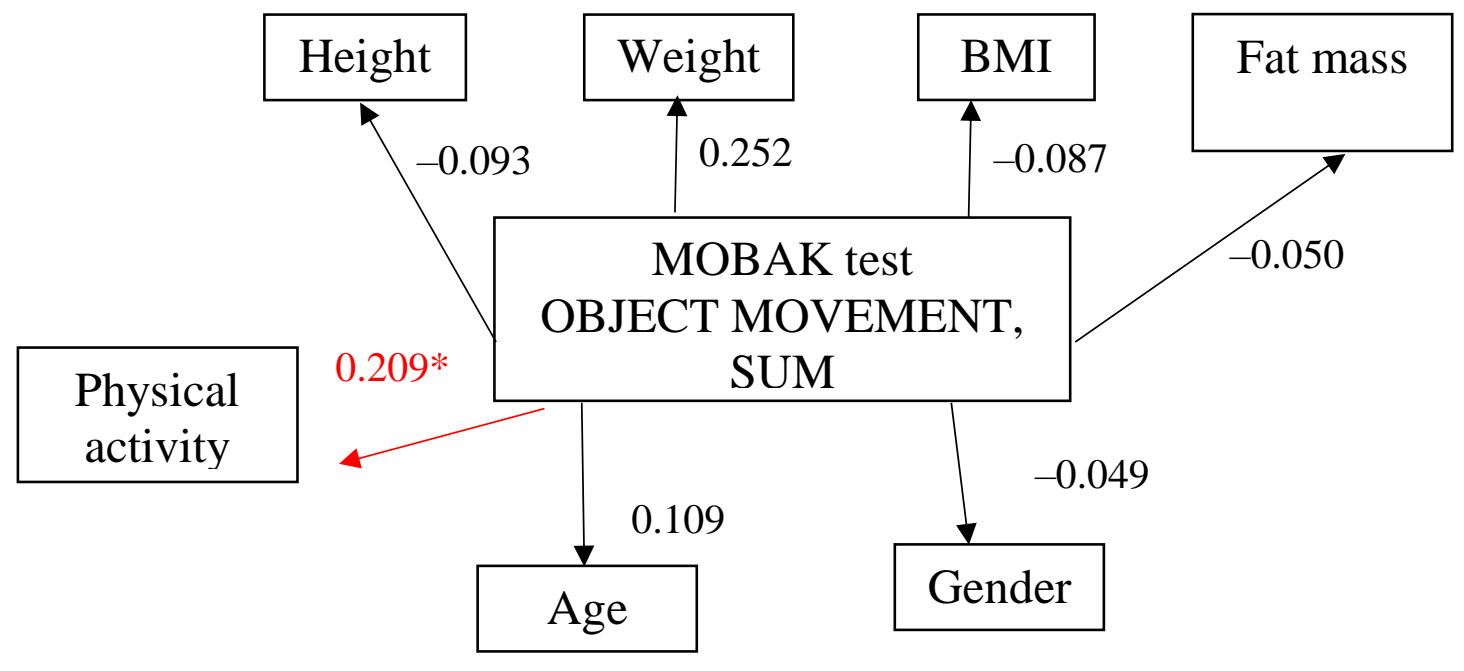

Note. $*-\mathrm{p}<0.05$.

Figure 2. "Object movement", sociodemographic, physical activity and anthropometric indicators

The second figure shows the statistically significant $(\mathrm{p}>0.05)$ difference between the selfcontrol test ratio and the body control and the amount of physical activity.

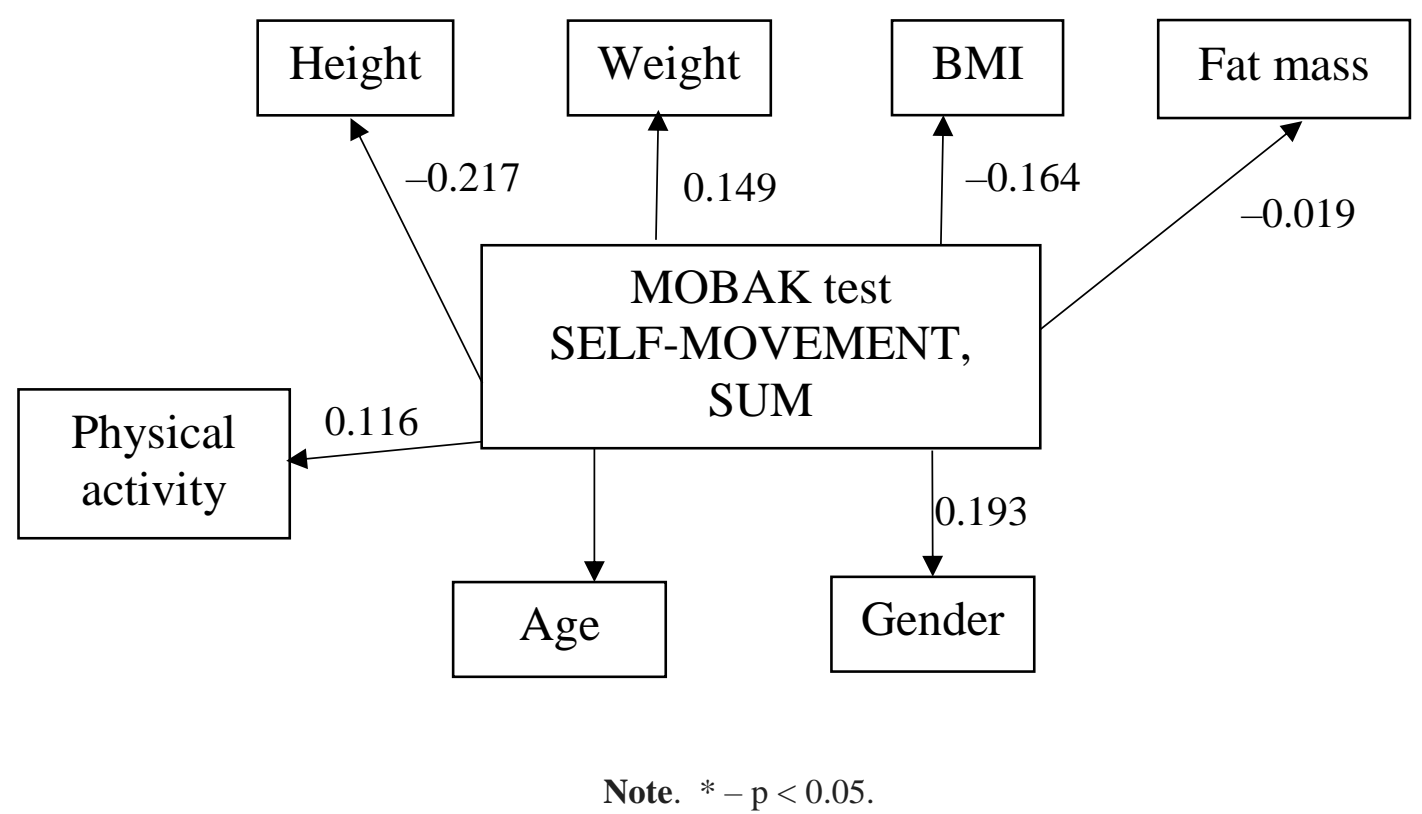

Figure 2. "Self- movement", sociodemographic, physical activity and anthropometric indicators 


\section{CONCLUSIONS AND DISCUSSION}

1. Results showed that there were relationships between MOBAK and physical activity in "Object movement" factor ( $\mathrm{p}>0.05)$.

2. There were no relationships between MOBAK and sociodemographic as well as anthropometric indicators $(\mathrm{p}<0.05)$ in "Object movement" factor $(\mathrm{p}<0.05)$.

3. Results showed that there were no relationships between MOBAK and physical activity in "Self-movement" factor $(\mathrm{p}<0.05)$.

4. There were no relationships between MOBAK and sociodemographic as well as anthropometric indicators $(\mathrm{p}<0.05)$ in "Self-movement" factor $(\mathrm{p}<0.05)$.

Research shows that the basic motor skills are the constituent parts physical activity, referred to as the basic conditions for participation in sports activities and sport - cultural life (Herrmann, 2015). This was not denied in our study. It reflects how different physical abilities that influence physical movement have a connection with motor skills. The main aim of this study was to analyse motor skills, which are divided into "self-management" and "object management" expecting them to be related to factors such as physical activity, physical fitness, anthropometric and sociodemographic indicators. Some studies suggest that the basic motor skills are closely related to gender (Cliff et al., 2009). Examples show that boys showed better motor skills, object management, and "selfmanagement" (Morgan et al., 2008; Barnett et al., 2009). Because of these gender differences it is important to examine the link between all motor skills, including self-management and object management separately for boys and girls. The examination of the accomplished research found early childhood relationships between the main motor skills and forms of physical activity of the boys (Cliff et al., 2009). By the way, the negative link was found between physical activity for girls and motor skills. Switching to late childhood age have been found in the interface between motor skills and physical activity "object management" among boys, and stronger links with the "object management" among girls (Hume et al., 2008; Morgan et al., 2008). Our study, however, did not find any link between gender and motor skills. We guess it should be a broader study examining the gender dimension deeper. Executive function is a key concept to describe the mental processes that involve the organization, behaviour management and operation of the memory processes (Haapala et al., 2013). The ability to control motor skills and improve them continuously can also be attributed to executive functions.

Recent studies have shown that motor skills have a negative link with the body mass index and body fat percentage, and are positively associated with physical activity levels (D'Hondt et al., 2009, 2011, 2013; Vandendriessche et al., 2011; Lopes et al., 2012). In our study we can see very similar results. Body fat mass did not interface with motor skills, but measured physical activity outside school hours affected their motor skills. The children are more interested in organized physical activity outside school hours as a leisure time, they better performed tests of MOBAK test battery. 


\section{REFERENCES}

1. Andersen, L. B., Harro, M., Sardinha, L. B. et al. (2006). Physical activity and clustered cardiovascular risk in children: A cross-sectional study (The European Youth Heart Study). Lancet, 368, 299 304.

2. Barnett, L. M., van Beurden, E., Morgan, P. J., Brooks, L. O., Beard, J. R. (2009). Childhood motor skill proficiency as a predictor of adolescent physical activity. The Journal of Adolescent Health, 44, 252-259. doi:10.1016/j.jadohealth.2008.07.004.

3. Cheatum, B. A., Hammond, A. A. (2000). Physical Activities for Improving Children's Learning And Behaviour: A Guide to Sensory Motor Development. Champaign, IL: Human Kinetics.

4. Clark, J. E., Metcalfe, J. S. (2012). The mountain of motor development: A metaphor. Motor development: Research and Reviews, 2, 163-190.

5. Cliff, D. P., Okely, A. D., Smith, L. M., McKeen, K. (2009). Relationships between fundamental movement skills and objectively measured physical activity in preschool children. Pediatric Exercise Science, 21, 436-449.

6. D’Hondt, E., Deforche, B., De Bourdeaudhuij, I., Lenoir, M. (2009). Relationship between motor skill and body mass index in 5- to 10-year-old children. Adapted Physical Activity Quarterly, 26 (1), 21-37.

7. D’Hondt, E., Deforche, B., Gentier, I. et al. (2013). A longitudinal analysis of gross motor coordination in overweight and obese children versus normal-weight peers. International Journal of Obesity (London), 37 (1), 61-67, doi: 10.1038/ijo.2012.55

8. D’Hondt, E., Deforche, B., Vaeyens, R. et al. (2011). Gross motor coordination in relation to weight status and age in 5- to 12-year-old boys and girls: A cross-sectional study. International Journal of Pediatric Obesity, 6 (2-2), 556-564, doi: 10.3109/17477166.2010.500388

9. Haapala, E. A. (2013). Cardiorespiratory fitness and motor skills in relation to cognition and academic performance in children: A review. Journal of Human Kinetics, 36 (1). doi:10.2478/hukin-20130006

10. Haywood, K. M., Getchell, N. (2015). Lifespan Motor Development (4th ed.). Champaign, IL: Human Kinetics.

11. Herrmann, C., Gerlach, E. (2014). Motorische Basiskompetenzen in der Grundschule. Pädagogische Zielentscheidung und Aufgabenentwicklung [Basic motor competencies in primary school. Pedagogical aim decisions and development of tasks]. Sportunterricht, 63 (11), 70.

12. Hume, C., Okely, A., Bagley, S. et al. (2008). Does weight status influence associations between children's fundamental movement skills and physical activity? Research Quarterly for Exercise and Sport, 79, 158-165. doi:10.1080/02701 367.2008.10599479

13. Linden C., Alwis G., Ahlborg, H. et al. (2007). Exercise, bone mass and bone size in prepubertal boys: One-year data from the pediatric osteoporosis prevention study. Scandinavian Journal of Medicine, Science and Sports, 17, 340-347.

14. Lopes, V. P., Stodden, D. F., Bianchi, M. M., Maia, J. A. R., Rodrigues, L. P. (2012). Correlation between BMI and motor coordination in children. Journal of Science and Medicine in Sport, 15 (1), 38-43, doi: 10.1016/j.jsams.2011.07.005

15. Morgan, P. J., Okely, A. D., Cliff, D. P., Jones, R. A., Baur, L. A. (2008). Correlates of objectively measured physical activity in obese children. Obesity (Silver Spring, Md.), 16, 2634-2641. doi:10.1038/oby.2008.463 
16. Stodden, D. F., Goodway, J. D., Langendorfer, S. J. et al. (2008). A developmental perspective on the role of motor skill competence in physical activity: An emergent relationship. Quest, 60, 290-306. doi:10.1080/00336297.2008. 10483582

17. Valdimarsson, Ö., Linden, C., Johnell, O., Gardsell, P., Karlsson, M. K. (2006). Daily physical education in the school curriculum in prepubertal girls during 1 year is followed by an increase in bone mineral accrual and bone width-data from the prospective controlled Malmo pediatric osteoporosis prevention study. Calcified Tissue International, 78, 65-71.

18. Vandendriessche, J. B., Vandorpe, B. F. R., Coelho e Silva, M. et al. (2011). Multivariate association among morphology, fitness, and motor coordination characteristics in boys age 7 to 11. Pediatric Exercise Science, 23 (4), 504-520.

\title{
BASIC MOTOR COMPETENCIES - MOBAK RELATIONSHIPS WITH ACTIVE LEISURE TIME, SOCIODEMOGRAPHIC AND ANTHROPOMETRIC INDICATORS
}

\section{Laura Tumynaitè}

Lithuanian Sports University, Kaunas, Lithuania

\begin{abstract}
Research background. Research literature has shown that the earlier studies rather narrowly focused on motor skills and competencies in physical activities in primary school children age groups. In the early childhood children begin to explore the environment and develop motor skills in certain groups. One of them is known as the fundamental motor skills, which are divided into "self-movement" and "object movement". "Self-movement" skills include body movements in space and are referred to as running, carrying, jumping, sliding and canter (Haywood, Getchell, 2015). "Objet-movement" skills consist of object manipulation and ability to control. "Object-movement" forms are throwing, catching, jumping, kicking, striking and tossing (Haywood, Getchell, 2005). These skills form the basis for future movement and physical activity (Clark, Metcalfe, 2012). One of the motor skills of the analytical methods is MOBAK (Herrmann et al., 2015) (the German translation of "Motorische Basiskompetenzen" (basic motor skills)) test battery, which is used in this study. We tried to discover the relationships between physical activity and sociodemographic as well as anthropometric indicators.
\end{abstract}

The aim of the research was to discover the relationships between MOBAK and physical activity, sociodemographic as well as well as and anthropometric indicators.

Results. Results showed that there were relationships between MOBAK and physical activity in "Object movement" factor ( $p>0.05)$. There were no relationships between MOBAK and sociodemographic and anthropometric indicators $(\mathrm{p}<0.05)$.

Conclusions. MOBAK test battery has relationships with physical activity. MOBAK test battery has no relationships with sociodemographic and anthropometric indicators.

Keywords: motor skills, physical activity, sociodemographic and anthropometric indicators. 